\title{
斜張橋の剛性による静力学的特性に関する一考察
}

\section{STATICAL FEATURES OF CABLE-STAYED GIRDER BRIDGES}

\author{
前田 幸 雄* - 林 正** - 井 本 賀 章*** \\ By Yukio Maeda, Masa Hayashi and Yoshiaki Imoto
}

\section{1. 緒言}

斜張橋の静力学的特性に関する研究として，すでに発

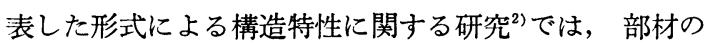
㖇性は一定にしたままで構造形式による特性を調べた が，本文では，代表的な 9 形式の 3 径間連続斜張橋につ いて,部材の剛性による静力学的な特性を明らかにした。

研究方法としては, 各部材の剛比を無次元パラメータ として参考文献”に示した弾性方程式に導入し，電子計 算機を利用したパラメータ解析を用いた。数值計算にお いては，塔およびケーブルの剛比を極限の值まで変化さ せて, 斜張橋の静力学的な弾性挙動に及ぼす剛性の影響 を調べた。

斜張橋のように多種類の構成部材を有する構造物の設 計においては，部材の剛比の選定に苦しむことが多いと 思われる。たとえば, 斜張橋は主析をケーブルで補剛し た構造形式であるから，その特質を生かすためにはケー ブルの剛性を大きくするほうがよい。しかし，それにも 限度があるはずであり, 適切な剛比の決定には迷うこと である。

構造物を合理的に設計するためには，その力学的性状 が明らかにされていなければならないが，斜張橋につい ては十分に研究されているとはいえず，参考資料も数少 ない。特に，剛性による特性を扱った研究としては，岡 内・安藤の研究 ${ }^{3)}$ があるが資料不足の感がある。このよ うな意味からも，本文に集録した資料が斜張橋の設計の 参考資料に加えられれば幸いである。

\section{2. 研究内容}

\section{(1) 研究方法}

斜張橋の各部材の剛性による弾性特性を, 大型電子計

* 正会員 工博 大阪大学教授. 工学部土木工学科

** 正会員 大阪大学助手同

*** 正会員 工修 日本鋼管（株）重工本部
算機を活用したパラメータ解析によって究明した。すな わち, 部材の剛性に関する断面諸量を無次元化したパラ メータとして弾性方程式に導入し，これらの值を変化さ せたときに得られる種々の応力および変形量の特性曲線 を描けば，そのパラメータに関する斜張橋の弾性特性を 知ることができる。

本文では，次の 4 個の無次元パラメータを用いた。 $\rho_{t}=h_{t} / l_{0}:$ 第 $t$ 塔のケーブル 取付け高さに関するパラ メータ

$\nu_{t}=E_{0} I_{0} / E_{t} J_{t}$ : 第 $t$ 塔の曲げ岡性に関するパラメータ $\kappa_{j}=E_{0} I_{0} / l_{0}{ }^{2} E_{j} A_{j}$ : 第 $j$ ケーブルの 伸び剛性に関する パラメータ

$r_{u}=\sum_{j=1,2,5,6} A_{j} / \sum_{j=1}^{8} A_{j}:$ 全ケーブルの断面積に対する上 段ケーブルの断面積の比に関するパラメータ

ここに, $h_{t}$ は第 $t$ 塔に属する上段ケーブルの塔との 取付点の高さ, $E_{t} J_{t}$ は第 $t$ 塔の曲げ剛性, $E_{j} A_{j}$ は第 $j$ ケーブルの伸び剛性を表わす。また， $l_{0}, E_{0} I_{0}$ は基準 長さおよび基準剛度で, 本文では主桁の全長および曲げ 剛性を選んだ。

\section{（2）研 究項目}

本文では, 次の 3 項目について斜張橋の剛性による静 力学的弾性特性を調べた。

(1) 塔の曲げ剛性による特性（ $\nu_{t}$ に関する特性）

(2) ケーブルの伸び岡性による特性（ $\kappa_{j}$ に関する特 性)

(3) 上・下段ケーブルの断面積比による特性（ $\gamma_{u}$ に 関する特性)

研究項目 (1)では, 斜張橋の各部材に生じる応力と変形 とに及ぼす塔の曲げ剛性の影響を調べる。項目 (2)では, 全ケーブルの断面積を変化させた場合の影響を, 項目 (3) では項目(2)とは逆に, 全ケーブルの断面積の総和を一定 にしたままで，上・下段ヶーブルの断面積の比を変化さ せた場合の影響を明らかにする。このとき，4 本の上段 
ケーブル（および下段ケーブル）は，同一断面を有する ものとする。

\section{（3）計算例（INPUT DATA）}

a) 構造形式

研究の対象とした斜張橋は，2 基の塔と 8 本のケーブ ルを有する対称な形である。主析は等断面の 3 径間連続 桁で，その径間比は $1.0: 2.5: 1.0$ とした。

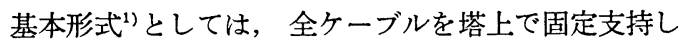
た $\mathrm{A}_{1-1}, \mathrm{~A}_{3-3}, \mathrm{~B}^{\prime}{ }_{1-1}$-type の 3 形式を用いた（図一1)。 ケーブルの張り方は，図一2 に示したような Radial， Harp, Star-type の 3 形式とした。したがって, 計算し た斜張橋の構造形式は, 図一1 と 2 を組合わせた 9 形式 となる。 $A_{1-1}$-type と図一2 の形式を組合わせた場合に は,

$$
\text { R.A } A_{1-1}, \text { H. } A_{1-1}, S . A_{1-1}
$$

のような記号で表わした。

ケーブルの主桁支持位置は, 主桁格点番号（図一3） を用いて表一1 に示した。

b) 無次元パラメータ

数值計算において用いた無次元パラメータの值は, 各 研究項目に対して表一2 のごとき組合わせを考えた。

表には非実用的な值を含んでいるが，これはそのパラ

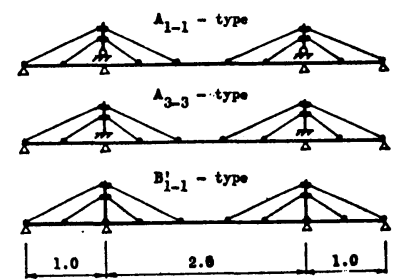

図一1 基 本 形 式
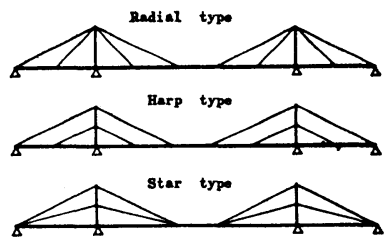

図一2 ケーブルの張り方

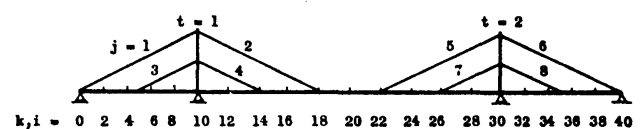

図一3 部材番号と主桁格点番号

表一1 ケーブルの主桁支持位四の格点番号

\begin{tabular}{l|c|c|c|c|c|c|c|c}
\hline Cable No. & 1 & 3 & 4 & 2 & 5 & 7 & 8 & 6 \\
\hline R. H-type & 0 & 5 & 14 & 18 & 22 & 26 & 35 & 40 \\
Star-type & 0 & 0 & 18 & 18 & 22 & 22 & 40 & 40 \\
\hline
\end{tabular}

\section{表一2 各研究項目において用いた無次元パラメータの值}

\begin{tabular}{l|l}
\hline (1) & $\begin{array}{l}\rho_{t}=0.1 \\
\nu_{t}=0,0.1,1,10,100,1000 \\
\kappa_{j}=10^{-5}, 10^{-4}, 10^{-3}\end{array}$ \\
\hline$\rho_{t}=0.1$ \\
$\nu_{t}=10$ \\
$\kappa_{j}=0,10^{-6}, 10^{-5}, 10^{-4}, 2 \times 10^{-4}, 3 \times 10^{-4}, 10^{-3}, 3 \times 10^{-3}, 10^{-2}$, \\
$10^{-1}, 1$
\end{tabular}

メータに関する極限の性状を知るためであって, 数值計 算においては，部材の破断や座屈などの現象を考慮して いない。

表一2 において用いた記号 $\Gamma$ は，全ケーブル断面積 の平均值に関する値であって,

$$
\Gamma^{-1}=\frac{1}{8} \sum_{j=1}^{8} \kappa_{j}^{-1}
$$

なる関係がある。研究項目 (1),(2)においては, 全ケーブ ルの断面積を同一としたから，

$$
r_{u}=0.5, \Gamma=\kappa_{j}(j=1,2, \cdots, 8)
$$

となる。

参考のために，わが国の著名な斜張橋 ${ }^{4), 5) に つ い ー ， ~}$ 一般図と無次元パラメータの值を本文の終りに示した。

c）荷重データ

主桁に載荷した荷重としては，主桁を 40 分割した格 点に単位集中荷重 $P_{i}=1$ を作用させた場合と, 図一4に 示したような 7 種類の単位等分布荷重 $w=1$ とを用い. た。これらを次のような記号で表わす。

$$
\mathrm{P}-1, \mathrm{~L}-0, \mathrm{~L}-1, \cdots, \mathrm{L}-6
$$
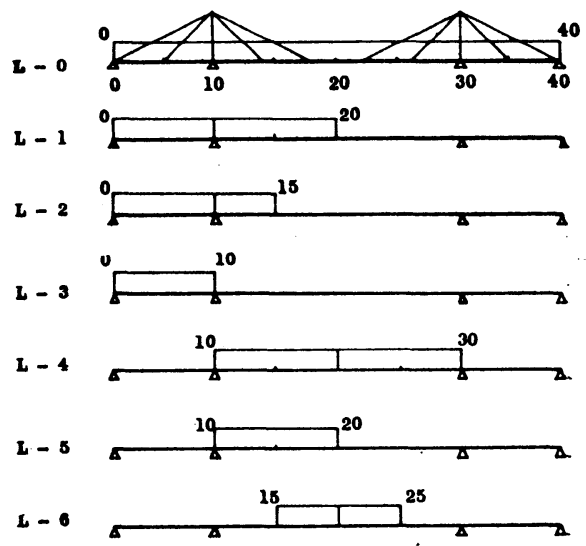

图一4等分布荷至の程類

\section{（4）計算結果（OUTPUT DATA）}

a) 計 算 值

各形式の斜張橋について, 前述の荷重に対する次の 100 種類の值を算出した。 
(1) ケーブル張力の鉛直成分 $V_{j}(j=1,2, \cdots, 8)$

(2) ケーブル張力 $X_{j}(j=1,2, \cdots, 8)$

(3) 塔基部の曲げモーメント $M_{t}(t=1,2)$

ただし， $A_{1-1}$-type では塔の中点における值。

(4) 塔基部の軸力 $N_{t}(t=1,2)$

(5) 塔頂の水平変位 $\Delta L_{t}(t=1,2)$

(6) 塔の部材回転角 $\beta_{t}(t=1,2)$ ただし, $\mathrm{A}_{3-3}$-type は除く。

(7) 主桁の支点反力 $R_{n}(n=0,10,30,40)$

(8) 主桁の軸力 $N_{k}(k=0,1,2, \cdots, 40)$

(9) 主桁の曲げモーメント $M_{k}(k=0,1,2, \cdots, 40)$

(10) 主桁のたわみ $\delta_{\boldsymbol{k}}(k=0,1,2, \cdots, 40)$

b) 特性曲線

計算結果を図示するために，縦座標には種々の荷重に よる部材の断面力または変形量をとったが, 集中荷重に よる場合には最大の影響值を示した。主桁に関する值で は, 特に着目断面を指示しない限り, 全格点における最 大値または最小値を用いた。また，塔の曲げモーメント は，その絶対値を示した。これらを， $\max V_{j}, \max M_{k}, \min M_{k},\left|M_{t}\right|$ などの記号で表わした。

\section{3. 剛性によるカ学的弾性特性}

すべての計算結果を示すことはとても不可能なことな ので，資料はほんの一部のみを示し，興味ある特性を要 約して箇条書きにした。

\section{（1）塔の曲け剛性による特性}

塔の曲げ剛性による影響は，塔に関しては当然著しい が，主桁およびケーブルに関しては比較的少ないといえ る。

塔の剛性が主桁の剛性の $1 / 10\left(\nu_{t}=10\right)$ のときには, 本文で扱った 3 基本形式の斜張橋はよく似た力学的性状 を示し ${ }^{2)}$ ，さらに塔の曲げ剛性の值が小さくなると， 3 基本形式はまったく同じ弾性挙動を示すようになる。

また, Radial と Star-type とでは影響は少なくて, Harp-type で最もよく現われる。特に， R. $A_{1-1}$ と . $A_{1-1}$-type では，塔の曲げ剛性は理論的に影響しない。

塔の曲げ剛性による特性は, ケーブルの剛性 $\left(\kappa_{j}\right)$ を 変えても同じような傾向であるので, グラフはすべて $\kappa_{j}=10^{-4}$ の場合を示した。

まず，塔の曲げモーメントについては（図一5）

a) H. $\mathrm{A}_{1-1}$ と $\mathrm{B}^{\prime}{ }_{1-1}$-type とでは, 塔に関して対称な 位置に荷重が載荷された場合には， $\nu_{t}$ の影響は現われ にくい。 $A_{3-3}$-type では Radial, Harp, Star-type とも 同じような傾向を示し，塔の剛性にほぼ比例するような
大きな曲げモーメントが生ずる。

ケーブル張力の鉛直成分については（図一6，7）

b) すべての形式において，荷重が塔に関して対称な 位置にある場合には，塔の曲げ剛性の影響は少ない。

c）影響がよく現われるのは，Harp-type の下段ケ一

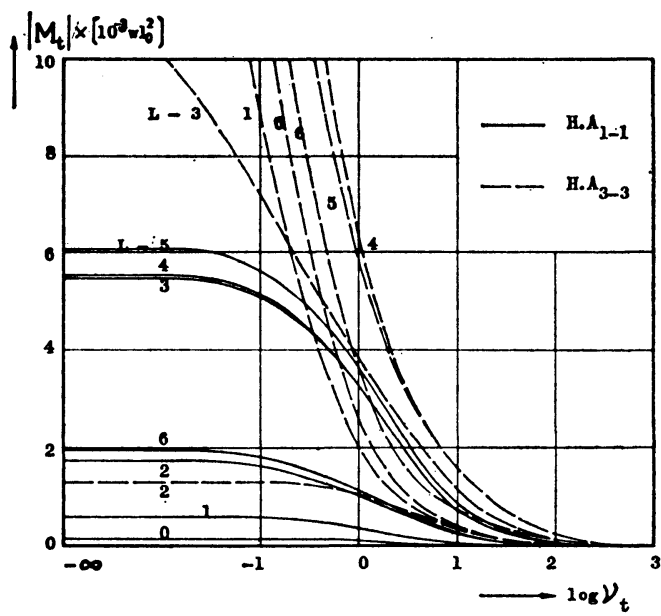

図一5第 1 塔曲げモーメントのע特性曲線

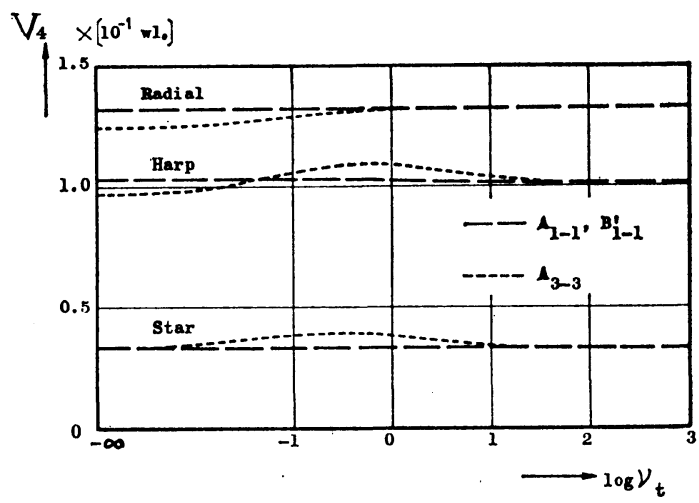

図一6 第 4 ケーブル張力鉛直成分の ע特性曲線 (L-0)

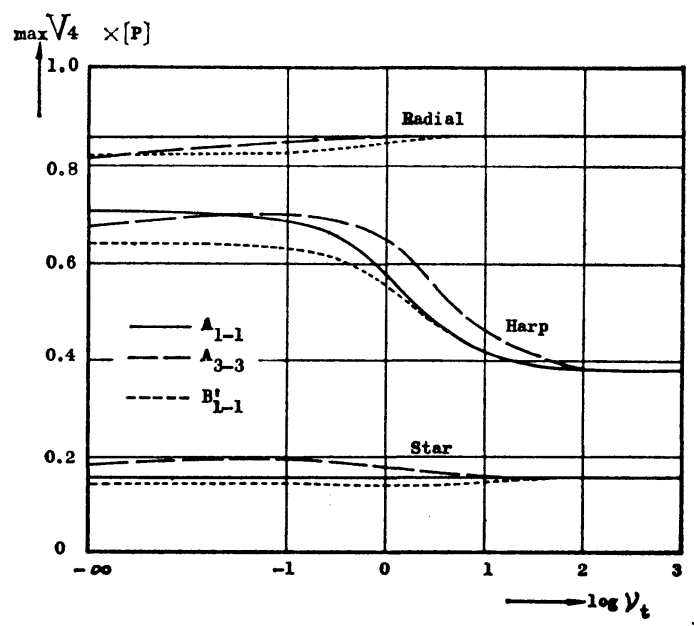

図一7 第4ケーブル張力鉛直成分の ע特性曲線 (P-1) 
ブル（第 3,4 ケーブル）で，上段ケーブルでは少ない。 したがって，主桁の曲げモーメントについて，次のよ うなことがいえる（図一8〜11）。

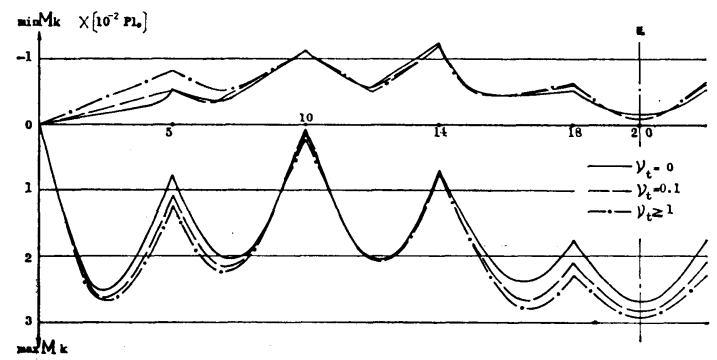

図一8主桁の最大・最小曲げモーメント図 (R.A $\left.A_{3-8} ; P-1\right)$

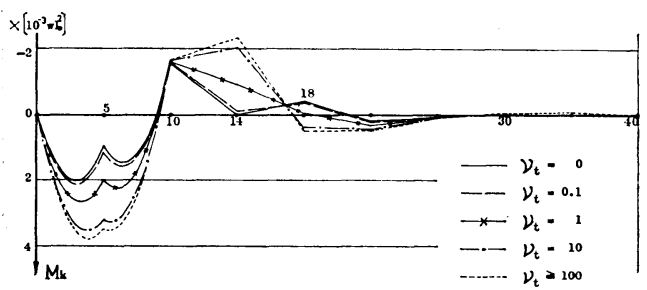

図-9 主行の曲げモーメント図 (H.A $\left.\mathrm{A}_{1-1} ; \mathrm{L}-3\right)$

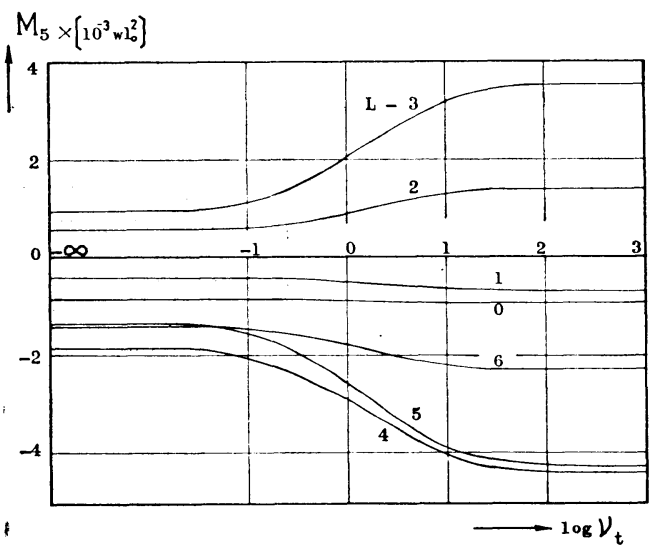

図一10格点 5 の主桁曲げモーメントの ע 特性曲線 (H. $\left.A_{1-1}\right)$

$\mathrm{M}_{0} \times\left[10^{-3} \mathrm{wt}^{-2}\right]$

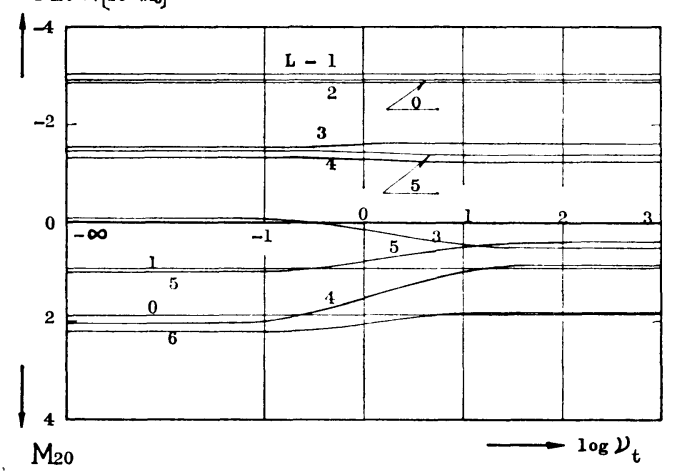

図一11格点 10 と 20 の主桁曲げモーメントの ע 特性曲線 (H. $\left.A_{1-1}\right)$ d） $\nu_{t}$ の影響は各基本形式とも Harp-type において 最む著しく, Radial と Star-type ではわずかである。

e) 荷重位置が塔に関して対称なときには, H.A $\mathrm{A}_{1-1}$ と $\mathrm{B}^{\prime}{ }_{1-1}$-type では $\nu_{t}$ の影響はほとんど認められない。

f）荷重位置が塔に関して非対称なときで，かつ， $\nu_{t}$ $=0.1 \sim 10$ のときに $\nu_{t}$ の值による影響が認められる。

g） $\nu_{t}$ の影響がよく現われる断面は，下段ケーブルの 主桁支持点 $(k=5,14)$ 付近であり, $\nu_{t}$ の值により 2〜 3 倍増減する。

断面 10 および 20 では， $\nu_{t}$ の影響は少ない。 主析と塔の軸力については

h) H. $A_{1-1}$ と $B^{\prime}{ }_{1-1}$-type では塔の剛性の影響はほと んどない。 $\mathrm{A}_{3-3}$-type では， $\nu_{t}$ の值の増加とともに軸力 も大きくなるが， $\nu_{t}$ の值が 3 以上になると影響しなく なる。

\section{（2）ケーブルの伸び剛性による特性}

ケーブルの伸び剛性による影響は，すべての部材にお: いて顕著に現われる。ケーブルの剛性をある有限の值ま で大きくすると, 斜張橋の弾性挙動は極限の状態に達し て，それ以上剛性を大きくしても影響しなくなる。

また，各基本形式における特性には，大きな相違点は ない。

ケーブル張力の鉛直成分については（図一12，13）

a) Radial と Harp-type の第 4 ケーブルでは， $\kappa_{j} \fallingdotseq$ $3 \times 10^{-4}$ のときに最大值を示すこともあるが，一般に剛

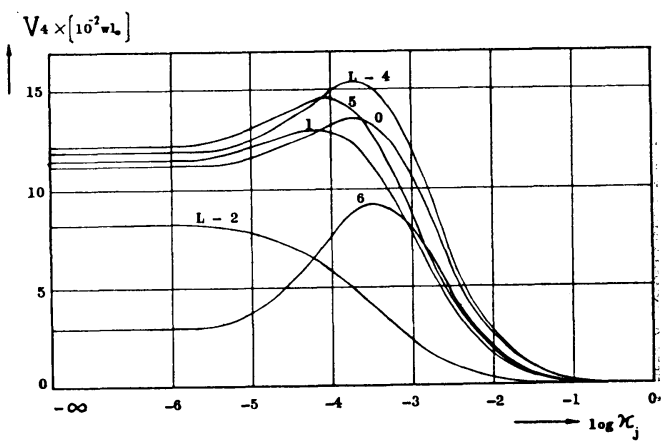

图一12 第 4 ケーブル張力鉛直成分の $\boldsymbol{x}$ 特性曲線 $\left(\mathrm{R} . \mathrm{A}_{1-1}\right)$

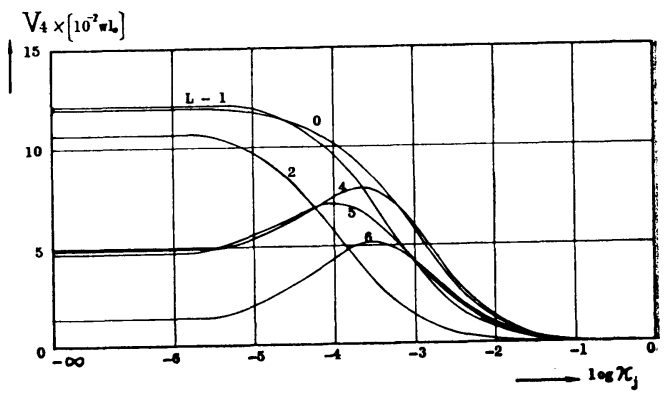

図一13 第 4 ケーブル張力鉛直成分の $\boldsymbol{x}$ 特性曲線 $\left(H . \mathrm{A}_{1-1}\right)$ 
性の低下とともに張力も減少する。

塔の曲げモーメントについては（図一14, 15）

b）斜張橋の形式および荷重により多少異なるが，ケ 一ブルの剛性がかなり低い $\left(\kappa_{j}=10^{-3} \sim 10^{-2}\right)$ ときに最 も大きな值が生じる。また， $\kappa_{j}$ の值が $10^{-5}$ より小さく なると，モーメントは一定值となる。

主桁の曲げモーメントについては（図一16〜19）

c）ケーブルの岡性の変化に対する曲げモーメントの 変化の割合は, $\kappa_{j}=10^{-4} \sim 10^{-2}$ のときに最も大きい。ま た， $\kappa_{j}<10^{-5}$ のときには，モーメントはほとんど変化 しない。

d） $\kappa_{j} \fallingdotseq 10^{-3}$ のときに, 斜張橋の主林の曲げモーメン

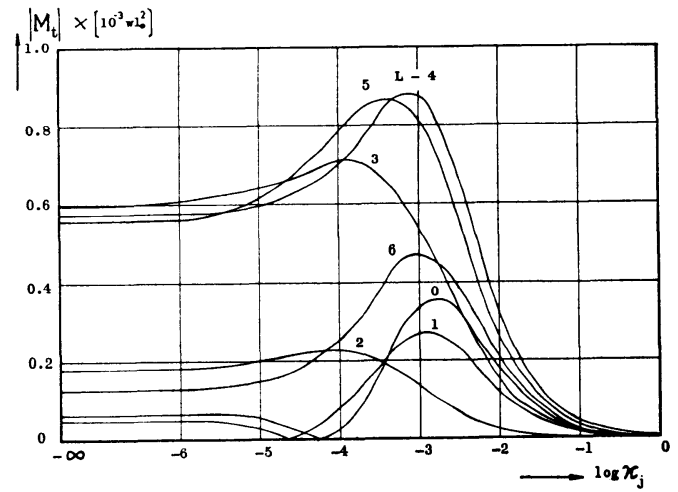

図一14 第 1 塔曲げ モーメントの $\boldsymbol{x}$ 特性曲線 $\left(H . \mathrm{A}_{1-1}\right)$

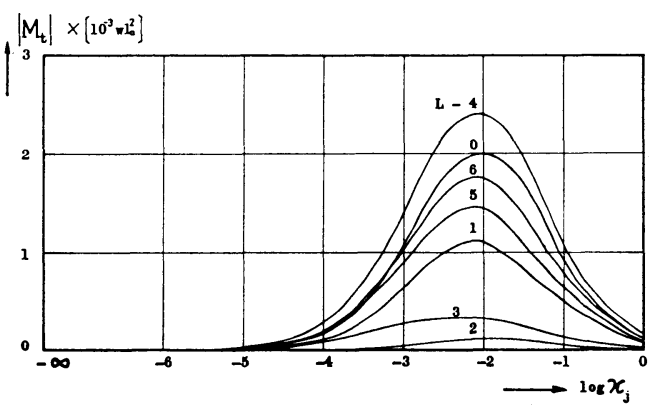

図一15 第 1 塔曲げモーメントの $\boldsymbol{\kappa}$ 特性曲線 (R. $\left.\mathrm{A}_{3-3}\right)$

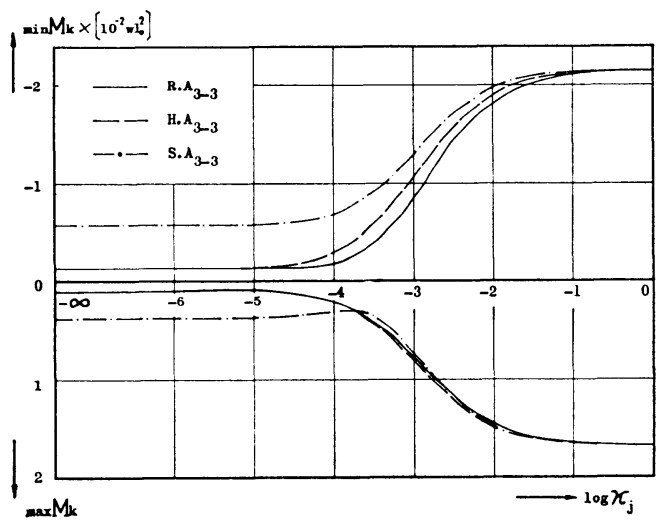

図一16 主桁曲げモーメントの $\boldsymbol{x}$ 特性曲線 $(\mathrm{L}-0)$

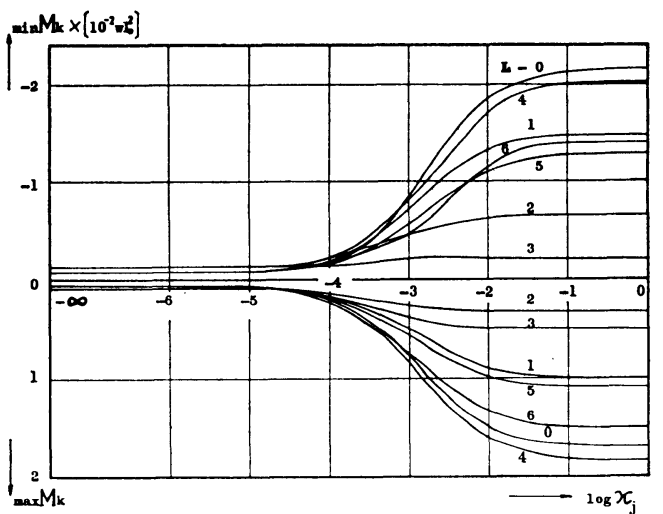

図一17主桁曲げモーメントの $\boldsymbol{x}$ 特性曲線 (R. $\left.A_{1-1}\right)$

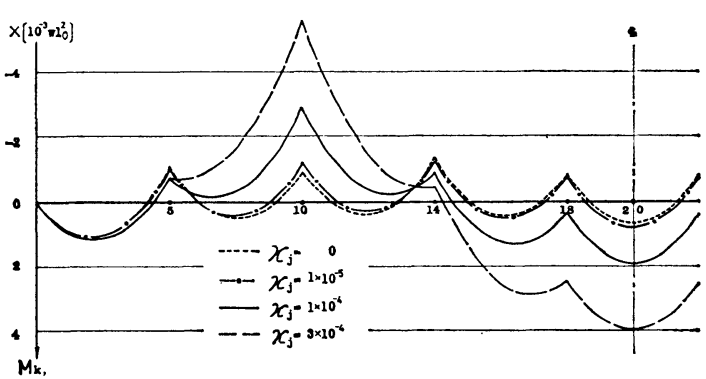

図一18 主枌の曲げモーメント図 $\left(\mathrm{H} . \mathrm{A}_{3-8} ; \mathrm{L}-0\right)$

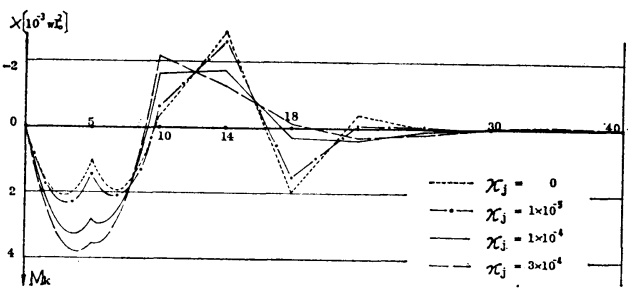

図一19 主桁の曲げモーメント図 (H. $\left.\mathrm{A}_{3-3} ; \mathrm{L}-3\right)$

卜は基本系である 3 径間連続桁の值の半分以下に減少す る。

主析および塔の軸力については

e) $\kappa_{j}=10^{-5} \sim 10^{-2}$ の間で, ケーブルの 剛性が増加す るにつれて一様に増加する。

\section{（3）上・下段ケーブルの断面積比による特性}

本節でも，塔の曲げモーメント以外は各基本形式とも 同じ傾向を示した。

ケーブル張力の鉛直成分について（図-20）

a) Radial と Harp-type では，ケーブルの総断面積 が大きい場合 $\left(\Gamma=10^{-5}\right)$ には, $r_{u}=0.2 \sim 0.8$ の間では 特性曲線はなだらかになる（図一20）。このことは，他 のケーブルおよび荷重についてもいえるので， $\quad \Gamma=10^{-5}$ のときには，上・下段ケーブルの断面積比を変えても諸 応力には大して影響しないことを意味する。

塔の曲げモーメント（図一21，22）

b） $\mathrm{A}_{1-1}$ および $\mathrm{A}_{3-3}$-type では, ケーブルの張り方 


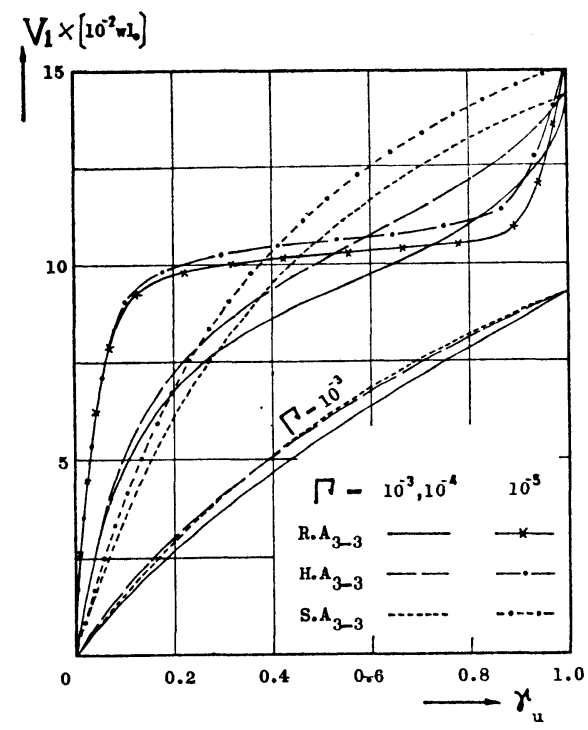

図一20 第 1 ケーブル張力鉛直成分の $\gamma$ 特性曲線 $\left(\mathrm{A}_{8-3} ; \mathrm{L}-0\right)$

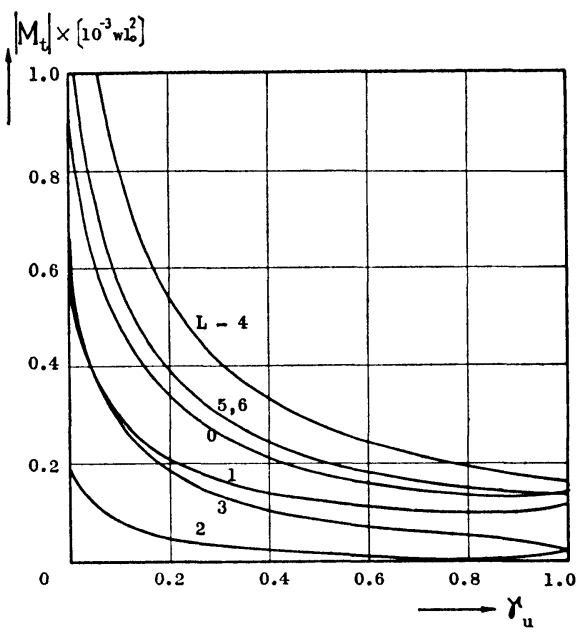

図一21第 1 塔曲げモーメントの $\gamma$ 特性曲楾 (R.A $A_{8-8} ; \Gamma=10^{-4}$ )

と荷重位置によらず， $\tau_{\boldsymbol{u}}$ が増加するにつれて曲げモー メントは減少する。

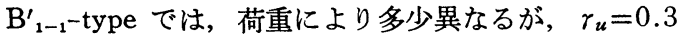
〜0.7 のときにモーメントは最小になる。そして，その 絶対量は，他の 2 形式に比べてずっと小さい。

主桁の曲げモーメント（図一23〜27）

c) $\Gamma=10^{-5}$ と $10^{-3}$ の場合には, 種々の荷重に対し ても図一23のような傾向を示す。

$\Gamma=10^{-4}$ のときには, 荷重により特性曲線の形状も変 わる(図一24, 25)。

d）主桁の各断面における影響は, Radial と Harptype では同じような傾向である（図一26，27）。

e) Star-type では, 荷重および $\Gamma$ の值によらず, $r_{u}$

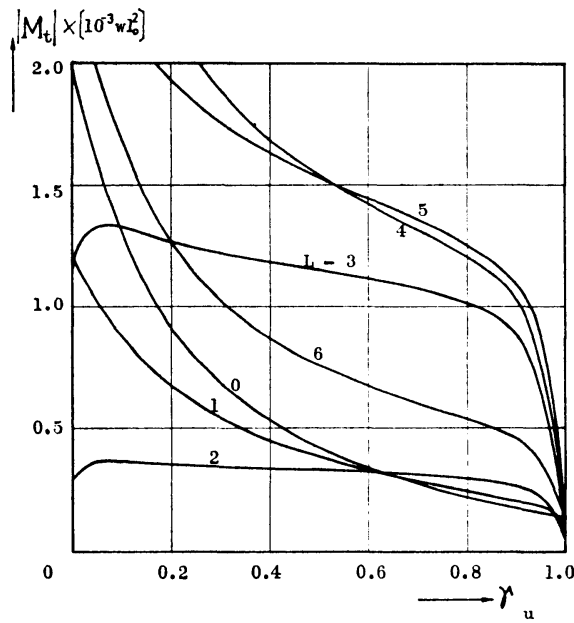

图一22第 1 塔曲げモーメントの $\gamma$ 特性曲線 (H.A $A_{8-8} ; \Gamma=10^{-4}$ )

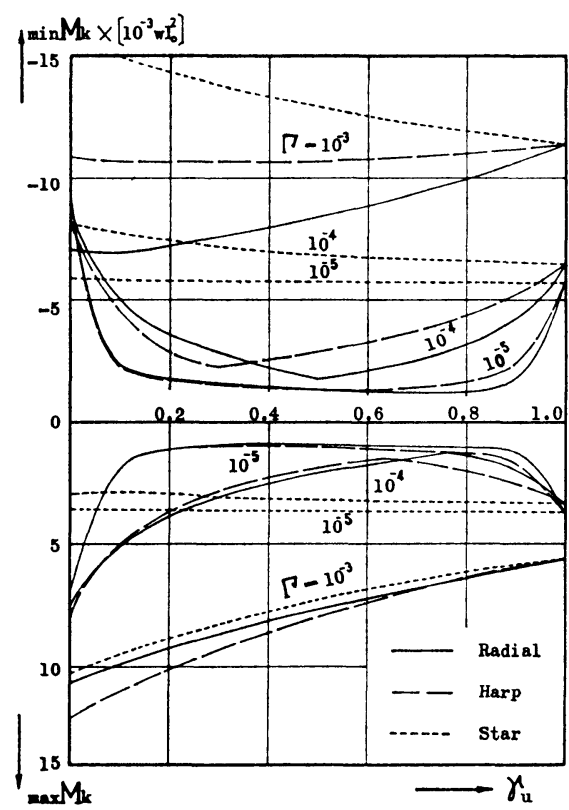

図一23主桁曲げモーメントの $\gamma$ 特性曲線 $\left(A_{8-8} ; L-0\right)$

の値が大きいほどモーメントの絶対量は減少する。 主桁の軸力については

f) Radial-type ではほとんど影響しないが，Harp と Star-type では $\gamma_{u}$ の増加につれて減少する。

\section{4. 静力学的特性に関する考察}

主桁の 径間比が $1.0: 3.0: 1.0$ の場合についても数 值計算を行なったので，これらの資料を加えて斜張橋の 静力学的特性を考察してみる。

主析の径間比が変わっても, 力学的特性はほとんど変 


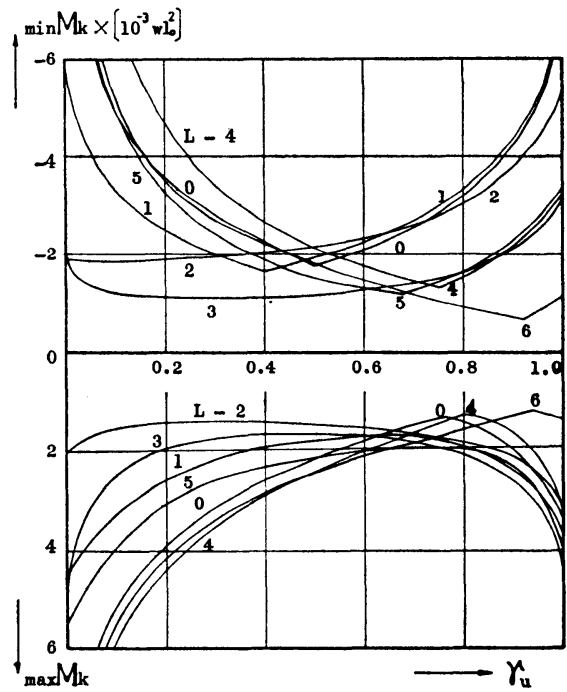

図一24主桁曲げモーメントの $\boldsymbol{\gamma}$ 特性曲線 (R.A $A_{1-1} ; \Gamma=10^{-6}$ )

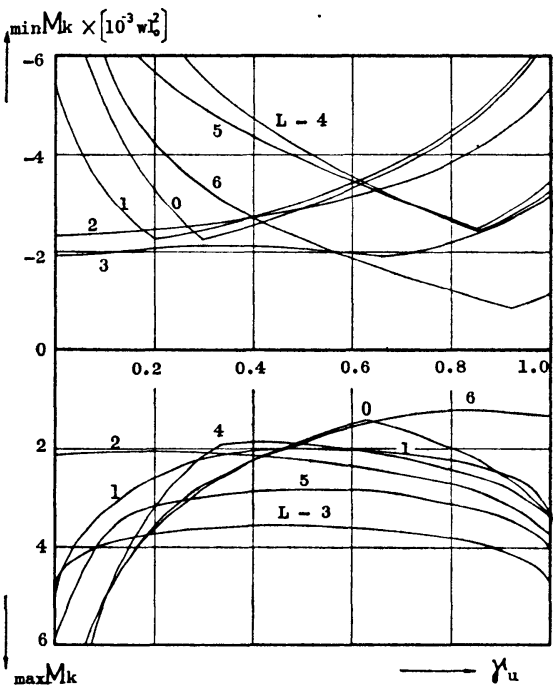

図一25 主桁曲げモーメントの $\boldsymbol{\gamma}$ 特性曲線 (H.A $A_{1-1} ; \Gamma=10^{-4}$ )

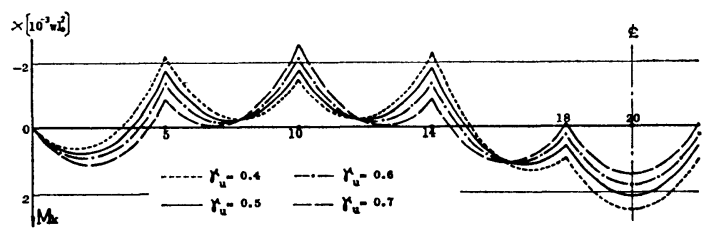

図一26主桁の曲げモーメント図

(R.A ${ }_{1-1} ; \mathrm{L}-0 ; \Gamma=10^{-4}$ )

わらない。もちろん個々の計算值は異なるが, 最も影響 が現われたのは H. $\mathrm{A}_{1-1}$-type の塔の曲げモーメントで ある。すなわち, ケーブルの配置が塔に関して非対称に なったために，塔に関して対称な荷重に対しても $\nu_{t}$ の 影響が大きく現われるようになった。

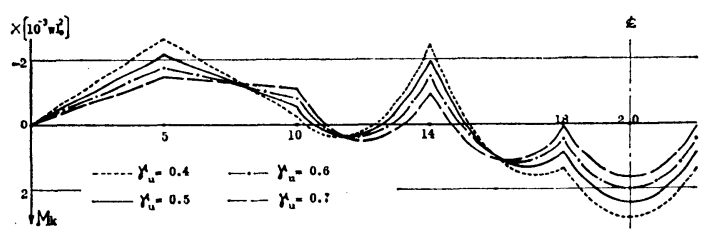

図一27主桁の曲げモーメント図

(R.A $A_{1-1} ; \mathrm{L}-4 ; \Gamma=10^{-4}$ )

本文の計算結果と構造特性に 関する 研究結 果 ${ }^{2}$ とか ら, 斜張橋の静力学的性状に最も大きく影響するものは ケーブルに関する諸条件であるといえる。まず，ケーブ ルの剛性については，一般に剛性の大きいほど主桁と塔 の曲げモーメントは減少する。しかし，あまりケーブル を太くしても意味がないことはすでに指摘したが，この 限界值は $\kappa_{j}=3 \times 10^{-5}$ ぐらいと判断される。

さて，全ケーブルについて一番大きな張力が生じるの は，荷重 L-0 が作用するときである。そこで，このと きすべてのケーブルの応力度がほぼ等しくなるような $\kappa_{j}$ の值を求めてみると， $r_{u}=0.5$ のときには Radialtype で $\kappa_{j}=\Gamma \fallingdotseq 2 \times 10^{-4}$, Harp-type で $\kappa_{j}=\Gamma \fallingdotseq 1 \times 10^{-4}$ となった。Star-type では，つねに上段ケーブルの応力 度が下段ケーブルの 1.6 1.8 倍になる。特に, 計算例 で扱った S.A $A_{1-1}$-type では，上・下段ケーブルの応力 度の比が剛比や荷重とは無関係に決まる。すなわち,

$$
\frac{\sigma_{u}}{\sigma_{l}}=\frac{h_{l}}{h_{u}} \times\left(\frac{\sin \alpha_{u}}{\sin \alpha_{l}}\right)^{2}
$$

ここに， $h_{u} ， \alpha_{u}$ は上段ケーブルの塔との取付け高さ とケーブルの傾斜角を， $h_{l}, \alpha_{l}$ は下段ケーブルのそれら の值を表わす。本文の計算例では，上式の值は 1.7474 になる。

こんどは逆に，すべてのケーブルの応力度が等しくな るような $\gamma_{u}$ の值を求めると， $\Gamma=10^{-5}$ と $10^{-4}$ のとき には, Radial-type で $\gamma_{u} \fallingdotseq 0.6$, Harp-type で $\gamma_{u} \doteqdot 0.5$, $\Gamma=10^{-3}$ のときには，それぞれ約 0.5 と 0.4 であった。 また, 主桁の径間比が $1.0: 3.0: 1.0$ のときには, Radial, Harp-type とも $\Gamma=10^{-4}$ のときで $r_{u} \doteqdot 0.6$ で ある。

図一24, 25 の特性図からは適正な上・下段ケーブルの 断面積比は決めがたいが, 上述のことより, Radial-type で $\gamma_{u}=0.6 \sim 0.7$, Harp-type で $\gamma_{u}=0.5 \sim 0.6$ ぐらい が適当ではなからうかと思われる。なお， Radial-type では，荷重 L-4 による場合も考慮して，第1ケーブル を一番太くするべきである。

次に, ケーブルの張り方と部材の剛性との関連性を調 べてみる。Radial-type では，ケーブルの剛性を増せば どのような荷重に対しても主桁の曲げモーメントは全径 間にわたって減少する。しかし，Harp-type では塔に 関して非対称な荷重が作用する場合には，ケーブルの剛 


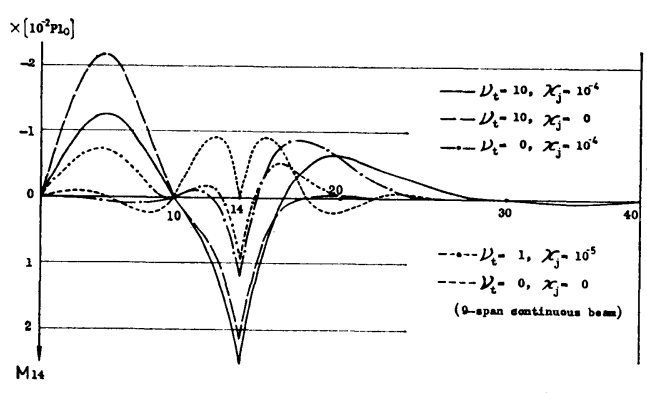

図一28格点 14 の主桁曲げモーメント影響線 (H.A (H-3 $\left._{3}\right)$

性を増しても主桁のモーメントは必ずしも減少しない (図一19)。

たとえば， $\nu_{t}=10$ のときにケーブルの 剛性のみを大 きくしても，第4 ケーブルの主桁支持点 $(k=14)$ では, その格点上に作用する荷重に対しては効果なく（図一 28），端径間に作用する荷重により大きな負モーメント が生じるようになる（図一19）。また, 格点 18 でも大き なモーメントが生じる。これは, 塔の曲げ変形によって ケーブルの上端が動くためである。むしろ，ケーブルの 剛性よりも塔の曲げ岡性を大きくするとモーメントは一 様に減少する (図一9, 28)。したがって, Harp-type に おいて主析の曲げモーメントを減少させるには, ケーブ ルの剛性とともに塔の剛性も大きくしなければ十分な効 果は現われない。ところが一方, 塔の剛性を大きくすれ ば塔に生ずる曲げモーメントも大きくなる（図一5)。

このような力学的性状から, Harp-type を採用する場 合には塔の剛性を大きくすることょりも，西ドイツの Knie 橋のように各段のケーブルの一方をそれぞれ不動 点に定着するほうが効果がある。さらに, ケーブルを塔 に関して対称形に張り, かつ, 最上段以外のケーブルを 塔上で滑動支持にして塔の曲げモーメントの減少をはか るのがよい。

以上のことより, 部材の剛性とケーブルの張り方につ いて，次のようなことがいえる。

(1) 塔の曲げ剛性については, Radial と Star-type では塔の耐荷力を考虑したうえで, なるべく剛性を小さ くするほうが経済的である。Harp-type では, 塔と主桁 の曲げモーメントの増減を考慮して適正な剛度を決定す る必要がある。

(2) ケーブルの剛性については， $\kappa_{j}$ の值が $10^{-4}$ 以下 になるとケーブルの断面積を增してもその効果は現われ にくくなる。

(3) 上・下段ケーブルの断面積比については, Radialtype では上段ケーブルの断面積が 下段ケーブルの 1.5 〜2.0 倍程度, Harp-type では同じぐらいか, やや上段 ケーブルを太くするほうがよいと思われる。Star-type は下段ケーブルを用いる意味がなく, 上段ケーブルを太
くするほらがよい。

(4) ケーブルの張り方については, なるべく塔に関し て対称形に張るのが望ましい。

(5) ケーブルを塔頂付近に集めると，主桁を支持する 効果が良くなり，かつ，塔の曲げモーメントも減る。

(6) ケーブルと塔との取付点の変位を少なくするよう に工夫する。それには, ケーブルの一端を不動点に定着 させるのがよい。また， Maracaibo 橋に用いられてい るような A-type の塔を採用するのもよいであろう。

\section{5. 結語}

本文では, 数百橋の斜張橋についての数值計算の結果 から, 斜張橋の静力学的な弾性挙動に及ぼす部材の剛性 の影響を定量的に明らかにした。その結果, 部材の剛性 に関するパラメータの值が， $\nu_{t}=1 \sim 10, \kappa_{j}=10^{-4} \sim 10^{-3}$ のときには, 剛比のわずかな変化が諸応力および変形量 に敏感に影響する。また, これらの值が実橋においてよ く用いられている值に近いことを考えれば，各部材の剛 比の決定には十二分に注意する必要がある。

この点に関し, 実橋に用いられているケーブルは, 一 般的に剛性がまだ低すぎると思われる。力学的には，も っとケーブルの断面積を増加すれば主桁の曲げモーメン トは減少する。このとき増大する主桁の圧縮軸力は, ケ ーブルを橋台または橋脚にアンカーすることにより, 少 なくすることができる6)。さらに追究すれば, これは最 適設計の問題となり, 今後の研究によらざるをえない。 ただ，今後の斜張橋の設計においては，主桁の剛性を減 らしてもっと柔な構造物にすべきであると考える。

通常, 設計においては数回の試算を繰り返す必要があ ろらが, 参考文献 1）で示した計算式は演算時間がきわ めて短いので, このような比較設計を行なう場合には便 利な式であるといえよう。

数值計算には,大阪大学大型計算機センターの NEAC 2200-M 500 と京都大学大型計算機センターの FACOM 230-60を用いた。計算時間は, FACOM を使用した場 合, 1 橋につき $5 \sim 6$ 秒であった。

\section{考文献}

1) 前田・林 : 任意な形状の斜張橋の解析, 土木学会論文集, 第 160 号, 昭和 43 年 12 月

2）前田・林：3 径間連続析を基本系とする 斜張橋の形式に よる静力学的構造特性に関する研究, 土木学会論文報告 集, 第 175 号, 昭和 45 年 3 月

3）岡内・安藤：斜張橋の特性に関する二, 三の考察, 第 22 回年次学術講演会講演概要, 昭和 42 年 5 月

4) 日本道路公団：尾道大橋設計計算書 (1968)

5）近藤他 5 名：豊里大橋, 三菱重工技報, Vol. 7, No. 7, 1970

6）前田・林・迫田：斜張橋の応力調整に関する二, 三の考 察, 第 25 回年次学術講演会講演集, 昭和 45 年 11 月 
参考盗 料

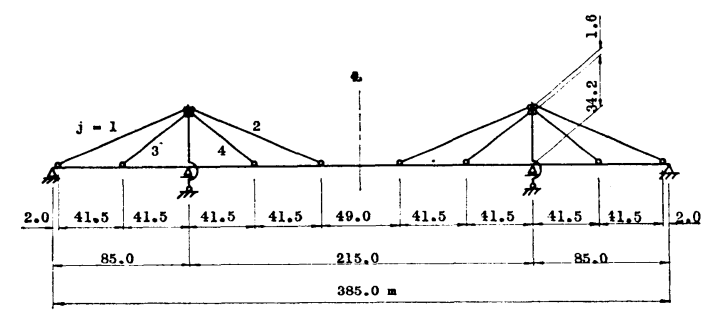

附図一1 尾道大橋一般図 (R. $A_{1-1}$-type)

附表一1 尾道大橋に関する無次元パラメータの值

\begin{tabular}{|c|c|c|c|c|c|}
\hline \multicolumn{2}{|c|}{ Main Girder } & \multicolumn{4}{|c|}{ span ratio $=1.0: 2.529: 1.0$} \\
\hline \multicolumn{2}{|c|}{ Tower } & \multicolumn{4}{|c|}{$\rho_{u}=0.0930, \rho_{l}=0.0888, \nu_{t}=10.26$} \\
\hline \multirow{3}{*}{ Cable } & No. & 1 & 2 & 3 & 4 \\
\hline & $\kappa_{j}$ & $1.326 \times 10^{-4}$ & $1.494 \times 10^{-4}$ & $2.218 \times 10^{-4}$ & $2.055 \times 10^{-4}$ \\
\hline & $r$ & \multicolumn{2}{|l|}{$\gamma_{u}=0.606$} & \multicolumn{2}{|l|}{$r_{l}=0.394$} \\
\hline
\end{tabular}

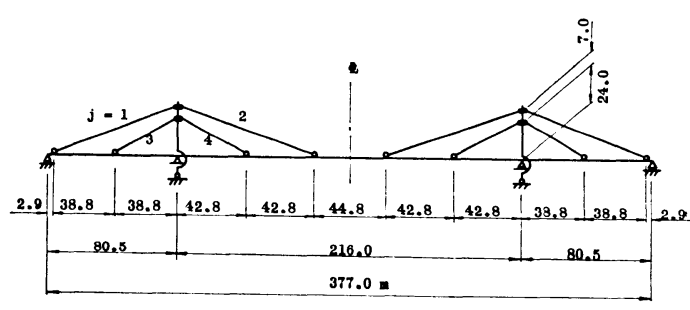

附図一2 曹里大橋一般図 (R-H. $A_{1-1}$-type)

附表一2 豊里大橋に関する無次元パラメータの值

\begin{tabular}{|c|c|c|c|c|c|}
\hline \multicolumn{2}{|c|}{ Main Girder } & \multicolumn{4}{|c|}{ span ratio $=1.0: 2.683: 1.0$} \\
\hline \multicolumn{2}{|c|}{ Tower } & \multicolumn{4}{|c|}{$\rho_{u}=0.0822, \rho_{l}=0.0637, \nu_{t}=10.68$} \\
\hline \multirow{3}{*}{ Cable } & No. & 1 & 2 & 3 & 4 \\
\hline & $\kappa_{j}$ & $1.472 \times 10^{-4}$ & $1.742 \times 10^{-4}$ & $1.962 \times 10^{-4}$ & $1.962 \times 10^{-4}$ \\
\hline & $r$ & \multicolumn{2}{|c|}{$r_{u}=0.572$} & \multicolumn{2}{|c|}{$r l=0.428$} \\
\hline
\end{tabular}

